BENCHIMOL, Jaime Larry.

Leishmaniases of the New World from a historical and global perspective, from the 1930s to the 1960s. História, Ciências, Saúde-Manguinhos, Rio de Janeiro, v.27, supl., set. 2020, p.95-122.

\title{
Leishmaniases of the New World from a historical and global perspective, from the 1930 s to the 1960s
}

\author{
Leishmanioses do Novo \\ Mundo numa perspectiva \\ histórica e global, dos anos \\ 1930 aos 1960
}

\author{
Jaime Larry Benchimol ${ }^{i}$ \\ 'Researcher and professor, Casa de Oswaldo Cruz/ \\ Fundação Oswaldo Cruz. \\ Rio de Janeiro - RJ - Brasil \\ orcid.org/0000-0002-6134-3336 \\ jailabench@gmail.com
}

Received on 16 Mar. 2020.

Approved on 2 Apr. 2020.

\section{Abstract}

The first autochthonous cases of cutaneous and mucocutaneous leishmaniasis in the Americas were described in 1909, but visceral leishmaniasis only erupted as a public health problem in the region in 1934. Today Brazil is the country with the most cases of American tegumentary leishmaniasis, and alongside India has the highest incidence of visceral leishmaniasis. Knowledge production and efforts to control these diseases have mobilized health professionals, government agencies and institutions, international agencies, and rural and urban populations. My research addresses the exchange and cooperation networks they established, and uncertainties and controversial aspects when notable changes were made in the approach to the New World leishmaniases.

Keywords: history of cutaneous and mucocutaneous leishmaniasis; history of visceral leishmaniasis in Brazil; Instituto de Patologia Experimental do Norte (Instituto Evandro Chagas).

\section{Resumo}

Os primeiros casos de leishmaniose cutânea e mucocutânea autóctones das Américas foram descritos e em 1909, em 1934 a leishmaniose visceral irrompeu como problema de saúde pública na região. $O$ Brasil tem hoje o maior número de casos da leishmaniose tegumentar americana e, junto com a Índia, a mais elevada incidência de leishmaniose visceral. A produção de conhecimentos e os esforços para controlar essas doenças mobilizaram, em nível global, profissionais de saúde, populações urbanas e rurais, instituições governamentais e agências internacionais. Recuperam-se aqui alguns desses agrupamentos, redes de troca e cooperação, incertezas e polêmicas, identificando-se mudanças na abordagem das leishmanioses do Novo Mundo.

Palavras-chave: história da leishmaniose cutânea e mucocutânea; história da leishmaniose visceral no Brasil; Instituto de Patologia Experimental do Norte (Instituto Evandro Chagas). 
$\mathrm{L}$ eishmaniasis is the only neglected tropical disease which is still growing, and Brazil $\mathrm{C}_{\text {is }}$ the country in the Americas with the most cases of this disease in its three forms: cutaneous, mucocutaneous, and visceral (WHO, 2017; OMS, 2010). In this article I will show how visceral leishmaniasis established itself as a public health problem in Brazil and the state of the art for all the leishmaniases in the 1960s, when they began to appear on the international health agenda.

In western medicine, production of knowledge on the different illnesses that would be grouped together as "leishmaniasis" in the early twentieth century is associated with European colonial expansion during the eighteenth and nineteenth centuries. In India, records of kala-azar, a disease that affected the internal organs (particularly the spleen and liver) and came to be known as visceral leishmaniasis, increased from the mid-nineteenth century onward, with an upsurge in the extremely deadly epidemics that depopulated various regions and villages in that British colony. It was initially associated with malaria or hookworm disease, and came to be integrated into the leishmaniasis complex in the early twentieth century, at the same time as dermatological diseases known in various parts of the world by a number of names indicating where and how they were acquired: Aleppo boil, Biskra button, Bahia button etc. "Oriental sore" was proposed in the 1870's as a generic designation to facilitate medical research on their nature. ${ }^{1}$

Leishmaniasis (a term which is so problematic when used in the singular) challenged the basic Pasteurian concept that each disease has a specific etiological agent, since these diseases with nothing in common were caused by protozoans that were indistinguishable utilizing the technical resources which were available at that time and for long afterward. The leishmaniases became the subject of intense scientific production in various parts of the world. Starting in 1909, Latin American physicians played an important role in this international network, with their research on the singular skin and mucosal manifestations of the disease which had another unique characteristic in the region: it was only acquired in forested areas, not urban centers, as in the Old World. The acceptance of the concept of "American tegumentary leishmaniasis" in the 1930s indicates the projection that Latin Americans achieved in the international network of tropical medicine. But for quite some time, what was unique about the Americas in terms of visceral leishmaniasis was the virtual absence of this form of the disease. One diagnosis was made in 1912 by a Paraguayan doctor, Luis Enrique Migone Mieres (1913), in an individual who worked on the construction of the Noroeste do Brasil railroad line. Four years earlier, this same railroad saw an outbreak of "Bauru ulcer," which was then recognized - for the first time in the Americas - as autochthonous cutaneous and mucocutaneous leishmaniasis. ${ }^{2}$

Visceral leishmaniasis only erupted as a public health problem in 1934. The Yellow Fever Service had just created a laboratory to analyze liver samples that hundreds of viscerotomy posts scattered throughout Brazil had collected from people who died from suspicious fevers. The pathologist Henrique Penna (1934) identified Leishmania in slides that tested negative for yellow fever, and as a result 41 deaths were suddenly related to visceral leishmaniasis.

With these postmortem case reports, Evandro Chagas (1905-1940) (the son of Carlos Chagas) found the first patient diagnosed while still alive in the northeast of Brazil. In a 
note published soon afterward (March 1936), this researcher at the Oswaldo Cruz Institute presented visceral leishmaniasis in Brazil as possibly differing from the forms observed in the Old World, even though it was impossible to differentiate the Leishmania found in Brazil, L. donovani, the agent of kala-azar in India and other parts of Asia, and L. infantum, the parasite described by Charles Nicolle in 1908 as the pathogen of infantile visceral leishmaniasis in the Mediterranean region (Chagas, 1936; see also Chagas et al., 1937). ${ }^{3}$

As head of an official commission to study visceral leishmaniasis, ${ }^{4}$ Evandro Chagas visited other places in the northeast, but soon moved his research to Pará, in northern Brazil. ${ }^{5}$ His investigation continued to be guided by reports from Yellow Fever Service pathologists. Evandro Chagas would make great efforts to demonstrate the nearly a priori theory of the alleged autochthony and specificity of "American visceral leishmaniasis." He sought to repeat the feat of those who had succeeded in establishing the concept of American cutaneous leishmaniasis and also of his father, who in 1909 discovered the famous American trypanosomiasis. Chagas was certainly influenced by the scientific effervescence caused by the discovery of sylvatic yellow fever, with the participation of the pathologist Henrique Penna (Soper et al., 1933).

Chagas and his collaborators stated that the disease occurred in individuals of different ages (especially those cases diagnosed posthumously through viscerotomies), while Mediterranean visceral leishmaniasis was mainly seen in children. In the Americas, the disease was only found in rural zones bordering wild areas, unlike kala-azar, which manifested as intense urban epidemics in India. Dogs were the main reservoirs in the Mediterranean zone, but could not play this role in a disease as sparse as the American one. Only wild animals acting as primary reservoirs could explain the epidemiological profile of American visceral leishmaniasis.

In incriminating a new species, Leishmania chagasi, as its causal agent, Evandro Chagas followed the example of Gaspar de Oliveira Vianna (1911), a pathologist at the Oswaldo Cruz Institute who had described Leishmania braziliensis, one of the many explanations offered for the unique characteristics of tegumentary leishmaniasis in the Americas. ${ }^{6}$ Vianna's and Chagas's theories were bolstered by the inclusion of nationalist ideologies in the medical debate, since an autochthonous protozoan species strengthened the symbolic capital of Latin American researchers within the international scientific network of tropical medicine.

The validation of Leishmania braziliensis is also related to the interpretation of preColombian ceramics which show human figures with lesions on the nose and mouth, considered proof that mucocutaneous leishmaniasis originated in the region. But the interpretation of these archaeological findings was not consensual; from the latenineteenth century, this had become a major controversy involving archaeologists, ethnologists, naturalists, and physicians from the Old and New Worlds, all disagreeing about the pathologies or practices suggested by these ceramics as well as by mummies, bone remains, and other pre-Colombian artifacts. To support their claims, these specialists used photographs and other iconographic representations from their own respective time periods to illustrate the effects of each disease being discussed. This discussion has significant heuristic value, since it reveals the complex of pathologies from which tegumentary 
leishmaniasis had to be untangled as it was being posited as a new disease native to the Americas, as shown in the study by Benchimol and Jogas Jr. (2020).

It is also important to remember the projection Gaspar Vianna achieved after his 1912 discovery that emetic tartar, a trivalent antimony compound, was effective in treating leishmaniasis, despite its toxicity. ${ }^{7}$ The drug was soon adopted in many countries and colonies, and had a strong impact on the mortality rates of kala-azar in India.

Evandro Chagas's theory about American visceral leishmaniasis largely stemmed from the fact that his research focused on the Amazon, where this form of the disease was scarce until the 1980s in comparison with the northeast of Brazil, or even in comparison with cutaneous and mucocutaneous leishmaniasis, which had been intense in the north of the country since the beginning of the rubber extraction economy. Evandro Chagas chose the Amazon because this was the only region where his political negotiations were successful, resulting in the creation of the Instituto de Patologia do Norte (Northern Pathology Institute, IPEN) in Belém, Pará, as a home for his studies. ${ }^{8}$

The first living cases of visceral leishmaniasis in the Amazon were found in a village called Piratuba, and a few more were later identified in three other municipalities in Pará: Marapanim and Soure, on the coast, by viscerotomy, and Moju, by clinical assessment. ${ }^{9}$ These cases corroborated the idea that the disease did not occur in towns or floodplains (that is, areas with major waterways or flooded areas), but rather on terra firma in forested areas with dry land and large concentrations of wild mammals. In Pará, seven naturally infected dogs and one cat were found. Granulations in a wild rodent (a tree rat, Phyllomys ssp.) suggested Leishmania, but this finding could not be confirmed. The most common species of fly suspected to transmit visceral leishmaniasis in the region were Phlebotomus longipalpis (Lutzomyia longipalpis) and Phlebotomus intermedius (Lutzomyia intermedia), but their role was not conclusively proven. ${ }^{10}$

Evandro Chagas and his collaborators established close connections with Argentinean physicians. In 1935, the son of Carlos Chagas participated in the ninth Meeting of the Argentine Society of Northern Pathology (SAPRN) in the city of Mendoza, which honored his father, at a crucial moment in the history of his discovery: Chagas disease was thrown into limbo as an illness with a supposedly limited magnitude, and its true epidemiological extent was revealed thanks to a type of conjunctivitis known as "Romaña's sign," which was discovered by a member of this society, Cecilio Félix Romaña. He joined the commission headed by Evandro Chagas and was part of the discovery of American visceral leishmaniasis.

Chagas's most prestigious international ally was Saul Adler, a Belarus-born physician educated in England who started his work at Hebrew University in Jerusalem in $1923 .{ }^{11}$ With the entomologist Oskar Theodor, he studied recognized or disputed species of Leishmania, developed ingenious serological methods to try to differentiate them, and investigated the known and alleged vectors of the parasite and zoogeography of leishmaniasis in the Mediterranean region. There was already strong evidence on the role of phlebotomine flies in transmitting the disease. In 1921, at the Pasteur Institute in Algeria, Edmond and Étienne Sergent and their colleagues demonstrated that Phlebotomus papatasi was able to transmit "Biskra button," the name for cutaneous leishmaniasis in that Algerian city: they were able to produce a skin lesion in a volunteer by inoculating crushed naturally infected flies (Sergent et 
al., 1921, 1926)..$^{12}$ Using a similar technique, Henrique Aragão of the Oswaldo Cruz Institute implicated Phlebotomus intermedius (Lutzomyia [Nyssomyia] intermedia) in the transmission of Leishmania braziliensis..$^{13}$ And Adler and Theodor in a similar way transmitted L. infantum to humans via Phlebotomus papatasi, ${ }^{14}$ but neither the Europeans who studied leishmaniasis in the Mediterranean region nor the British and Indians investigating kala-azar in Asia were able to experimentally transmit the parasite to human volunteers through bites from flies that had previously fed on patients with the disease (the decisive proof).

It was only in 1942, in Assam (one of the Indian states most affected by visceral leishmaniasis) that Henry Edward Shortt and his team proved that humans contracted kala-azar after being bitten by $P$. argentipes previously infected on sick patients. As KillickKendrick (2013, p.134-135) and Desowitz (1991, p.17-18) explain, this was largely due to a fundamental technical innovation. Chagas, Adler and other researchers followed methods adopted to study the malaria/mosquito relationship by successive blood meals, but in Leishmania this produced non-infectious flies. However, a diet of raisins (i.e., sugar) following an infectious blood meal surprisingly caused the flagellates of Leishmania to multiply sharply in the body of the insect.

In a study published shortly before the conclusion of this research, Adler (1940a) made an interesting summary of the frustrated attempts to experimentally infect humans; the most recent at that time were those of Evandro Chagas and his colleagues. ${ }^{15}$

In September 1939, Adler sent Evandro Chagas a paper that was published in the journal of Oswaldo Cruz Institut (Adler, 1940b). "So far it has been impossible to distinguish L. chagasi from L. infantum by any laboratory test,"16 wrote Adler (1940b, p.173), but he proposed other arguments to justify this distinction. First, in the Old World, distribution of $L$. infantum and L. donovani was "rigorously confined" to Phlebotomus species of the major group that were not found in the Americas. The synonymity between L. chagasi and L. infantum assumed that the latter had been exported to the Americas. However, Adler argued that the existence of L. braziliensis in pre-Columbian America (based on the archaeological findings mentioned above) and of a related species of the parasite in the Old World (L. tropica) when there was no communication between the two continents was as indication of the possible antiquity of Leishmania chagasi. The exportation of $L$. infantum to the Americas was considered unlikely because, in his own words, "Up to the present there have been no proved instances of the formation of new foci of L. infantum even in the Old World itself "where the disease is remarkably static in its distribution'" (Adler, 1940b, p.174; my emphasis).

On November 8, 1940, Evandro Chagas died at age 35 in a plane crash in Guanabara Bay. Studies on visceral leishmaniasis lost momentum in Brazil, and at the same time the first major epidemiological survey on American tegumentary leishmaniasis was begun by Samuel Barnsley Pessôa (1898-1976), parasitologist in the recently inaugurated University of São Paulo.

In the inland regions of São Paulo state where the disease was endemic, the activities carried out by the Leishmaniasis Study Commission created through an agreement between the Parasitology Department of the São Paulo School of Medicine and the São Paulo State Department of Health were prolonged for two and a half years (1939-1941) until they were 
abruptly ended by the state government, largely because of the problems these activities caused for large rural landowners, especially those who divided up part of their properties to create smaller farms or urban settlements in areas that had already been cleared. The epidemiological investigation led by Samuel Pessôa showed that the incidence of the mucosal forms of the disease was much higher than imagined. It also showed that the share of women among leishmaniasis victims had been hidden by the fact that it was mostly men seeking to support their families who went to the larger cities to seek medical care, and only there the disease was registered. The Commission brought care to the rural areas and treated more than nine thousand patients with cutaneous lesions or severe mucosal lesions. Promising experiments were done with a vaccine made from dead cells of various strains of Leishmania braziliensis.

Of the 34 species of phlebotomine flies identified in the state of São Paulo, the Commission confirmed that only three (Phlebotomus whitmani, P. pessoai, and P. migonei [Lutzomyia whitmani Antunes e Coutinho, 1939; Lutzomyia pessoai Coutinho e Barretto, 1940; and Lutzomyia migonei França, 1920]) seemed to play an important role in transmitting cutaneous and mucocutaneous leishmaniasis. These species accounted for nearly all the phlebotomine fauna in the zones with high and low endemicity, which were more precisely demarcated.

Besides nearly sixty articles appearing in various domestic periodicals, Samuel Pessôa and his colleague Mauro Pereira Barretto published Leishmaniose tegumentar americana in 1948; this award-winning text became a classic work on this topic and decisively helped solidify this long-lasting concept, particularly among Latin American specialists. ${ }^{17}$

During the post-war period, developmentalist nationalism was embraced by many teachers and researchers in the traditional medical schools and those which were being created around Brazil, as well as by sanitarians, who found promising professional prospects in the health services created after the 1930 revolution which brought Getúlio Vargas to power. Mário Pinotti, the head of the National Malaria Service, led the team responsible for the health program of Juscelino Kubitschek, elected president in 1956 on the promise of "50 years of progress in 5 years of government."18 The living conditions of rural workers were expected to improve with eradication or control of endemic diseases in the interior of the country, using specific strategies tailored to the biological and social peculiarities of each disease and the availability of antibiotics, insecticides, vaccines, and other prevention or control techniques. Also influential were the priorities established as international health agencies played an increasingly important role in decisions by the governments of Brazil and other countries.

While diagnoses of tegumentary leishmaniasis increased in number, there were few in vivo cases of visceral leishmaniasis. Since the first diagnosis in 1912, 34 cases had been recognized in living patients in Brazil and only 35 in the Americas. Viscerotomies indicated 314 more widespread deaths between 1934 and 1950 (Deane, Deane, 1955b).

But in 1953, an epidemic broke out in northeastern Brazil that dramatically changed this situation. In only five years (1953-1957), the total number of in vivo cases jumped from 34 to 1,832 , the majority (81.38\%) in the state of Ceará. In the Americas the number rose to 2,179 (1,840 living cases and 339 postmortem), but more than $98 \%$ of the total $(2,145$ cases) were found in northeastern Brazil (Deane, 1958). 
At that time a devastating drought punished the region, and thousands of people left in search of food, shelter, and work. In the press and among the doctors and the people, there was much talk of "calazar." Contemporary investigations showed that it had gone unnoticed for quite some time. The few previous diagnoses did not reflect the rarity of the disease, but rather the lack of medical assistance available to the rural population and scarcity of knowledge among the doctors working in the interior. A campaign against visceral leishmaniasis began in Ceará under the leadership of Joaquim Eduardo Alencar, one of the founders of the Ceará School of Medicine in 1947, where he taught parasitology. After visiting the stricken region, Samuel Pessôa sent two of his assistants, Leônidas Deane (1914-1993) and his wife Maria von Paumgartten Deane (1916-1995) (both former members of Evandro Chagas's team) to the region.

There they found a fox (Lycalopex vetulus) infected with Leishmania (Deane, Deane, 1954). They thought they had been the first to find a wild animal with visceral leishmaniasis, but soon learned that three Russians had just verified in Central Asia (Tajikistan) that the jackal (Canis aureus) also acted in this role (Latyshev, Kryukova, Povalishina, 1951). ${ }^{19}$ While this confirmed the wild reservoir that Evandro Chagas had sought, the rest of the observations made by Leônidas and Maria Deane and local researchers seriously undermined the theory proposed in the 1930s. Now the disease did not depend on the forests; it could occur in urban areas, and even in the rural zones, where it was predominant, it had a "focal" character. Urban transmission was confirmed by individuals and especially dogs infected in the cities. ${ }^{20}$

Most of the rural cases were concentrated in areas known as boqueirões and pés de serra, narrow valleys between mountains or in their foothills. In the arid sertão and verdant highlands, infection was infrequent and cases were sparse and sporadic. The endemic area was soon extended after investigations by local physicians in the northeast and north of the country; initially, the Jaguaribe River valley, where a recent campaign against Anopheles gambiae had taken place, and later the banks of the Piancó River in Paraíba (Alencar, Holanda, Cavalcante, 1956; Alencar, 1962). ${ }^{21}$

And how was calazar combated? As in other parts of the world, through DDT spraying. ${ }^{22}$ Phlebotomine flies disappeared from the treated houses, but the insecticide was active for less time in animal shelters outdoors and useless in peri-domicile areas. Intra-domiciliary transmission could be reduced because $P$. longipalpis attacked mostly at night, when the human population was inside their homes, but transmission outdoors was the Achilles' heel of that prophylactic strategy. The antilarval measures that were so important in yellow fever and malaria were not applicable against this disease since larvae of $P$. longipalpis had been found in the earth beneath trees, not in aquatic environments. In fact, the breeding habits of this and other species of sandflies were still poorly understood.

The spraying was done by the National Malaria Service according to the habits of Anopheles, which were not the same as Phlebotomus. "Spraying was not done to the necessary extent," complained Alencar (1961, p.178), "nor was it done at the suggested time, preceding the rains, after which the density of phlebotomine flies increases, and with it contagion intensifies."

The campaign against visceral leishmaniasis in the northeast of Brazil also involved the discovery and elimination of canine cases. In an interview, Filipe DantasTorres (29 nov. 2016), a veterinarian and researcher at the Aggeu Magalhães Institute (Oswaldo Cruz 
Foundation) stated that only Brazil and China may have killed dogs on such a large scale in order to control leishmaniasis. In fact, in his habilitation thesis on canine leishmaniasis, Alencar (1959) used the Chinese experience as his main reference, for there the strategy against kala-azar relied mainly on destroying the intermediate host of Leishmania donovani. His main sources were Chung (1940), who advised elimination of sick dogs, and a paper on New China's achievements in treating and preventing kala-azar which was presented by Lu et al. (1955) at a scientific meeting sponsored by the USSR Academy of Medical Science and the Ministry of Public Health of the Uzbek Soviet Socialist Republic in September 1954 at Tashkent.

Alencar and the physicians who worked on the Brazilian campaign against calazar had no doubts that the socioeconomic conditions of rural workers in the northeast of Brazil were largely responsible for the prevailing epidemics. A statement attributed to Alencar (1961, p.175-176) sums up the situation perfectly: "Leishmaniasis is a disease of dogs and of those who lead a dog's life." Consequently, prophylaxis needed to include improving the living conditions of affected populations. In practice, however, actions related to the human populations were limited to systematic treatment with pentavalent antimonial drugs, chiefly Glucantime (Rhône-Poulenc-Rohrer) and Solustibosan (Bayer), which were provided to hospitals and health centers at no charge.

In 1958, the Ministry of Health under Juscelino Kubitschek promised to eliminate five endemic diseases: yaws, Chagas disease, goiter, trachoma, and leishmaniasis. ${ }^{23}$ That same year, the fifteenth Pan American Sanitary Conference in Puerto Rico approved a resolution declaring the Panama Canal Zone, Brazil, and nine other countries free of Aedes aegypti, the urban vector of yellow fever. Also in 1958, Brazil officially joined the worldwide campaign to eradicate malaria. These events marked an era of sanitary optimism which a decade later began to give way to the uncertainties of the present day. Meanwhile, activities against rural endemic diseases rolled out throughout Brazil. Studies at that time showed that the emigration of people from the northeast increased the incidence of the leishmaniases in other regions of the country. The number of cases diagnosed in the interior grew alongside those in the big cities, where ever-greater numbers of rural workers migrated. Awareness also spread that isolated cases of visceral leishmaniasis needed to be investigated, since they were likely to be linked to new endemic areas.

These epidemiological surveys were made possible by transformation in the public health apparatus at the federal and state levels, and by strengthening the institutional network to house studies on the leishmaniases and other rural endemics. The medical schools in São Paulo and Ribeirão Preto (SP) (this latter created in 1947) and the Oswaldo Cruz Institute in Rio de Janeiro were the main nodes of this network, which included the Institute of Preventive Medicine at the University of Ceará, the Evandro Chagas Institute, the Special Public Health Service (SESP) and three research centers established in the late 1950s by an important arm of DNERu (abbreviation of the National Department of Rural Endemic Diseases), the National Institute for Rural Endemic Diseases (INERu): the Bahia Research Center, in Salvador (later called the Gonçalo Moniz Research Center), the Belo Horizonte Research Center (which would be called the René Rachou Research Center), and the Aggeu Magalhães Research Center in Recife (which derived from Evandro Chagas's 
initiatives and had already conducted important research on schistosomiasis). Work in these institutions (since the 1970's subordinated to Oswaldo Cruz Foundation) focused mainly on schistosomiasis, Chagas disease and malaria, but visceral leishmaniasis gained importance in studies involving cooperation from the universities of Pernambuco, Bahia, and Minas Gerais.

A landmark in the consolidation of this research network was the Kala-azar Seminar held in Salvador, the capital of Bahia, in 1960 (Notas Médicas, 1 nov. 1960; 10 nov. 1960; 23 nov. 1960). Experts interested in this endemic disease (but who also worked with others) met for the first time, and on the opening day of the event the Brazilian Society of Tropical Medicine (Sociedade Brasileira de Medicina Tropical) was founded (Notas Médicas, 20 nov. 1960).

\section{Tropical medicine in the context of the Cold War}

Tropical medicine also gained renewed importance internationally, because the traditional diseases in this category began to appear as significant obstacles (and byproducts) to development policies targeting countries like Brazil to lift them out of their "underdeveloped" status; more notably, it was important to prevent them from escaping their orbits around the capitalist world through popular rebellion propitiated by poverty and disease.

Let us put this into context with a quick sketch of the background at this time.

In the years following the end of the Second World War, during the lead-up to the Cold War, the institutional arrangements and political alignments which characterized the field of health began to change and diversify. The establishment of a bipolar geopolitical order exacerbated antagonisms and placed limits on how multilateral or global health concepts could be applied.

The bilateral approach adopted by the United States during the Second World War through the Good Neighbor Policy was further solidified with the creation of or encouragement to create different health institutions and services. Notable in Brazil were the maintenance of the Special Public Health Service as a strategic agency for American and Brazilian interests in the north and northeast regions of the country (Campos, 2006) and initiatives by the Rockefeller and Kellogg Foundation and the Pan American Sanitary Organization (later called the Pan American Health Organization, PAHO) to organize or reformulate medical education in Brazil and other Latin American countries based on the American or Flexnerian model (Edler, Pires-Alves, 2018; Kemp, Edler, 2004; Cueto, 2015). This model valued the connection between research, teaching, and clinical practice and attributed specialized technologies and practices the power to "solve" health problems in the region. This belief reached its zenith in the campaigns to eradicate or control malaria and other diseases through insecticides or chemical therapy in verticalized activities. The health optimism that reigned during the post-war period was important in mobilizing the medical field and one of the keys to the multilateral linkages that led to the design of international health in this period during which two agencies emerged. The Pan American Sanitary Organization and the World Health Organization (WHO) played an important role 
in reflections on health and development and in proposing agendas to confront diseases and other health problems at the global and regional levels. Starting in 1947 under the leadership of Fred Soper Lowe, who was highly regarded for his work on campaigns against yellow fever and malaria in the region, the PAHO placed great emphasis on training human resources for health and proposing strategies for the governments of the Latin American countries to face common health problems. For example, this commitment can be seen in the organization of the Pan American Health Conferences, which from 1947 were dedicated to the theme of international health and its challenges (Lima, 2002; Cueto, 2015).

The World Health Organization fostered discussions on health and development, especially during the management of the Brazilian Marcolino Gomes Candau, who in 1953 was elected the organization's second director-general and was reelected to serve four successive mandates, until 1973. The withdrawal of the Soviet Union and its allies from the UN system (including WHO) between 1949 and 1956 reinforced the perception that this system was dominated by the interests of the United States (Brown, Cueto, Fee, 2006). In addition to articulating major campaigns for disease control or eradication and planning regional and multilateral health strategies, WHO played a fundamental role in reformulating the system of validating medical and health knowledge through its world health assemblies, international conferences, and reports and opinion papers produced by experts it recruited to present their opinions on specific topics.

At this point in the post-war period, ideas about tropical diseases and medicine's ability to transform underdeveloped countries like Brazil were strongly influenced by an economicist vision of health planning, based on analysis by authors such as Charles-Edward Amory Winslow (1955) and Gunnar Myrdal (1952) about the vicious circle of poverty and disease. According to these authors, socioeconomic development could only be achieved by combating the large-scale diseases that impeded it.

On March 13, 1961, US president John F. Kennedy made a famous speech at the White House before Latin American ambassadors introducing the Alliance for Progress, a development assistance plan for Latin America that would be formalized five months later when the United States and 22 other nations in the Americas (including Brazil) signed the Charter of Punta del Este. The notion of inter-American cooperation had been proposed in 1958 by Juscelino Kubitschek: the so-called Pan American Operation (OPA) was based on the idea that only by eliminating poverty on the continent could communism be contained and democracy expanded. The victorious socialist revolution in Cuba in January of 1959 convinced the formulators of hemisphere policy in Washington that they needed to be more sensitive to increasing demands for economic development and social progress from Latin America. The traditional policy based on the assumption that private capital alone would permit economic growth in the region had faltered (momentaneously, as we can see today).

The Charter of Punta del Este recognized the urgent need for social, economic, and political transformations in the Americas. The short-term goals of the Alliance for Progress were to bring about changes in the daily life of the Latin American masses who faced challenges with housing, clothing, nutrition, and literacy, and in the longer term involved reforms that would ensure socioeconomic development and boost quality of life in each 
country through national development plans, economic integration, stabilizing raw material prices, and financial restructuring. In the meeting held in Punta del Este, Uruguay, in August 1961, the United States committed to providing a substantial portion of the 20 billion dollars that Latin America would need to complement with its own resources over the next ten years.

Throughout this decade, which was marked by a succession of military coups that shook the continent, the Alliance for Progress was heavily criticized by experts, who attacked its weak structure and unrealistic goals, as well as liberal and leftist sectors that viewed it as an instrument of American economic and strategic interests (Kramer, s.d.; Aliança..., s.d.).

In 1962, the year of the Cuban missile crisis and exacerbation of the Cold War, a comprehensive study on tropical diseases and the resources for their study and control was completed in the United States. ${ }^{24}$ The study, which was sponsored by the National Academy of Sciences and the National Research Council, had support from the most important American agencies (the Office of the Surgeon General, the National Institutes of Health, US Public Health Service, and the Rockefeller Foundation). Its Consultant Committee, chaired by Albert B. Sabin, was a team of heavyweights that brought together health, industry, and business. The arguments justifying the relevance of the study clearly show concern with preserving a power with imperial ambitions from the dangers that threatened it: decolonization movements, revolutions, and communism.

Nearly half the world's population was in the tropics, hundreds of millions of people living in poverty, but "ever less willing to spend their short lives dreaming about rewards from beyond, desiring a better life here and now" (NAS, 1962a, p.VII). The tropical world was seen as a powder keg, ready to explode. The decolonization movements demanded a redefinition of how tropical medicine had been practiced until that time. The relationship between the old metropolises and their colonies, through services and institutes with interests and jurisdiction limited to the areas of each metropolis, had lost its reason for being. The new world order, established under the leadership of the United States, demanded new roles for this country on a global scale.

The Committee headed by Sabin proposed a National Program for Tropical Health Research, paid for by the National Academy of Sciences and the National Research Council, to articulate and strengthen existing programs, especially in fields that received little or no attention, and to encourage the training of researchers in the country and abroad.

The authors of Tropical health: a report on the Study of Needs and Resources stirred up controversy with a Malthusian train of thought that did not have a favorable view of "premature" improvements in public health in the tropical regions, since they would intensify already rapid population growth far beyond what the local economies could bear. For Sabin and his peers, control of widespread diseases would lead to an increase in the proportion and productivity of workers within the population as a whole, giving them "more strength and ambition" to explore new lands or recover those which had been abandoned or considered impenetrable because of disease (NAS, 1962a, p.IX). I note here that this is precisely the factor which was most conducive to the spread of leishmaniasis and diseases that would later be classified as emerging. 


\section{Leishmaniases: state of art}

To analyze the state of the art in relation to leishmaniasis, Leônidas Deane of the medical school at the University of São Paulo was consulted, along with Marshall Hertig of the Gorgas Memorial Laboratory (Panama) and Philip Edmund Clinton Manson-Bahr, a British physician then connected to the Department of Health in Nairobi, Kenya. ${ }^{25}$ But before we examine their opinions, we need to add another initiative to this scene: in 1960, the World Health Organization commissioned Percy Cyril Claude Garnham, a professor at the London School of Hygiene and Tropical Medicine, to perform a study on the problems related to leishmaniasis, amebiasis, the trypanosomiases, and toxoplasmosis on a global scale, diseases which had previously been underestimated by that agency. One notable aspect of his report regarding the leishmaniases is the contrast between the fixed epidemiological scenario described by Adler in the 1930s and its fluidity in the 1960s.

Observations in Russia and Iran had demonstrated the existence of two clinical forms of cutaneous leishmaniasis, dry and wet, which were epidemiologically and serologically different. The classic form was dry, in the cities; the wet type was more severe, and occurred in rural areas, steppes and deserts (Garnham, 21 jun. 1960, p.13). ${ }^{26}$ From the Mediterranean basin, especially Italy and North Africa, cutaneous leishmaniasis expanded its territory. Each year thousands of cases occurred in Iraq, Iran, Lebanon, Syria, Russia, Pakistan and India. According to Garnham, slow expansion through the Sahara spread cutaneous leishmaniasis to Sudan, Ethiopia, French West Africa, Nigeria, and Ghana. The equatorial forest seemed to block the advance to the south, but it was critical to determine whether there was danger that the disease would spread widely across Africa (Garnham, 21 jun. 1960, p.12-13).

In visceral leishmaniasis, Garnham distinguished the classic form (kala-azar), the Mediterranean or "infantile" form, forms from Sudan and East Africa, and also "aberrant" leishmaniasis. The epidemiological characteristics differed, and the vectors and reservoirs of the causal agent were still largely unknown. Kala-azar mainly occurred on the Indian subcontinent - India and Pakistan, the latter country recently dismembered from the former after the end of British colonialism in the region. The disease prevailed in other parts of Asia (Bhutan, China, Turkistan, Russia), the Middle East, and on the Mediterranean coast and islands. It was also spreading through Africa; it had reached Kenya via Egypt and Sudan, northern Nigeria and French West Africa through the Sahara. While the total number of cases in the Americas soared impressively from 35 to more than 2,179 cases in the 1950s, this surge pales in comparison with the fragmentary data compiled by Garnham: in hospitals and dispensaries in West Bengal there were 38,848 cases in 1951, and ten thousand cases in Sudan in 1959 (Garnham, 1960, p.11). In Kenya, a smaller epidemic in 1960 caused about one thousand deaths. Visceral leishmaniasis became a major problem in Sudan and in East Africa at a surprising speed, and there were fears that the disease would spread throughout sub-Saharan Africa.

The experts consulted for the American study agreed that visceral leishmaniasis had diminished after DDT sprayings as part of the malaria eradication programs, but they feared that sandflies and the diseases they transmitted would reappear when spraying ceased. It is important to recall that the international campaign to eradicate malaria was already 
foundering, in large part due to the DDT resistance seen among Anopheles mosquitoes. Many initiatives were taken at the time to evaluate the true dimension of this problem and to find alternatives. Richard Fay, of WHO's Environmental Sanitation Division, asked Leônidas Deane (19 abr. 1960) to investigate the susceptibility of Phlebotomus longipalpis to DDT and Dieldrin. Experiments done by a technician at the Belo Horizonte Research Center under Deane's supervision led to the conclusion that these insecticides remained effective in destroying the main vector of visceral leishmaniasis in the Americas, a fact that "naturally removes from the problem ... the urgency with which it presents itself in the case of anophelines" (Falcão, 1963, p.411). ${ }^{27}$

Hertig proposed systematic control in the Old and New World, but Manson-Bahr thought it unlikely that DDT would affect the incidence of visceral leishmaniasis in East Africa; in fact, it increased in Sudan after some malaria control activities. The British researcher believed that the epidemiology of visceral leishmaniasis there was different, and very little was known about the reservoirs, vectors, and other aspects of the disease.

Work in Peru showed that good protection could be obtained against uta, one of the forms of American tegumentary leishmaniasis, by applying DDT in dwellings and animal sheds and on nearby surfaces, such as stone walls and tree trunks. In Peru, Phlebotomus species spread both uta and Peruvian warts (verruga peruana, a phase of Carrion's disease, or bartonellosis), and the incidence of both had fallen, but control of tegumentary leishmaniasis among populations living in forested areas was still unsolved. In Panama, separating dwellings from the forest with a cleared zone was seen to provide a certain degree of protection. When Hertig visited Costa Rica with the entomologist Alexander Graham Bell Fairchild, at the invitation of that country's government and the International Cooperation Administration (ICA), they suggested experimental use of DDT in forests. ${ }^{28}$

It should be said in passing that a similar practical challenge occurred with bromeliad or forest malaria, first described by Adolpho Lutz (1903, p.282-292) and in the 1950's studied by Garnham and Deane (who collaborated closely) in Brazil and Africa. In 1954, this form of malaria sickened approximately four hundred people in Trinidad, the largest and most populated of the 23 islands that comprise Trinidad and Tobago, a British colony that would only gain its independence in 1962. The program to eradicate this disease focused on Anopheles bellator, which reproduces in the water that accumulates in bromeliad plants. Employees of the Trinidad and Tobago Health Department tried to eradicate bromeliads with copper sulfate (Malaria..., 1954). In certain forest areas of Brazil like Santa Catarina, insecticides, larvicides and chemical substances were also sprayed to destroy bromeliads, resulting in severe environmental impacts that would only be acknowledged afterward (Thiago, 2003, p.43).

According to the specialists involved in Tropical health: a report, the two essential aspects of all forms of leishmaniasis remained partially or entirely unsolved: the reservoirs of Leishmania and the means of transmission for the diseases it caused in man. They had evidence that all the leishmaniases were transmitted by phlebotomine sandflies, but not necessarily only these insects. In Kenya, for example, the role of termites was investigated. ${ }^{29}$ Deane felt an urgent need to determine the vector species of Phlebotomus in each region and study their bionomics: domesticity, longevity, seasonal variation, food preferences etc. 
Another fundamental problem which remained unsolved involved the natural hosts of Leishmania, starting with humans. The so-called aberrant clinical forms manifested long after an apparent cure in cases of cutaneous or visceral leishmaniasis, and it was therefore crucial to know whether these patients were still infectious. The diagnostic methods did not address the problem and often were not specific, with cross-reactions occurring with Chagas disease and other infections.

Studies on the reservoirs had to be extended to wild animals. For visceral leishmaniasis, Deane had incriminated wild foxes, and Soviet researchers, the jackals. Ronald B. Heisch then found Leishmania in rodents in Kenya. In the Mediterranean region and in China, infected domestic dogs were considered the main reservoirs. ${ }^{30}$ Meanwhile in India, for reasons that were not yet explained, dogs were not infected, and humans were assumed to be the only reservoir there.

As for cutaneous leishmaniasis in the Old World, dogs were found to be sensitive to inoculation with Leishmania tropica minor, the agent of the classical (dry) form in cities, but this did not affect transmission of the rural (wet) disease. Infected desert rodents, especially the gerbil (Rhombomys opimus), had been found in Turkmenistan, ${ }^{31}$ Iran, and in Soviet Central Asia. For Garnham and the other participants in this discussion, further study of Old World cutaneous leishmaniasis as a zoonosis was required.

This issue took on more importance in New World cutaneous and mucocutaneous leishmaniasis, which was almost always associated with forests. According to many Latin American researchers, dogs were rarely infected by $L$. braziliensis. ${ }^{32}$ The most promising results were obtained by Aristides Herrer (1948; 1949-1951), of the Lima National Institute of Hygiene and Public Health. In an area of Peru where uta was raging, $40 \%$ of the 469 dogs Herrer examined were infected. ${ }^{33}$ As for wild animals, since 1922 Émile Brumpt had included a photo of an agouti (Dosyprocta azarae) in the third edition of his Précis de parasitologie, first published in 1910; he had seen the animal in an endemic zone of São Paulo with ulcers identical to leishmaniasis, but was unable to find parasites in them. Pedro Weiss, of the Lima Institute of Hygiene and Public Health, examined 750 animals in regions of Peru where espúndia was epidemic, without success. Pessôa and Barretto (1948) were also unsuccessful in their tests in agoutis, nutrias (rato do banhado, Myocastor coypus), monkeys, wild pigs etc. Oswaldo Paulo Forattini and his colleagues at the School of Hygiene and Public Health of the University of São Paulo examined 928 specimens of forest animals and obtained positive blood cultures for Leishmania in only three: a wild rodent (Kannabateomys amblyonyx amblyonyx), a paca (Cuniculus paca paca), and an agouti (Dasyprocta azarae) (Forattini, 1960b). ${ }^{34}$ In Panama, the wild reservoirs of Leishmania remained equally uncertain. ${ }^{35}$

This subject was closely related to another issue, which Leônidas Deane posed in his opinion paper "What is the systematic position of the different Leishmania in man?" (NAS, 1962a, p.505).

Leishmania donovani (Laveran and Mesnil, 1903), L. tropica (Wright, 1905), and L. braziliensis (Gaspar Vianna, 1911) denoted the parasites for human and canine visceral leishmaniasis, cutaneous leishmaniasis, and American tegumentary leishmaniasis, respectively. Specific or subspecific names had been assigned to Leishmania isolated in certain regions, particularly in Latin America, threatening in this case the sovereignty of L. braziliensis. 
This tendency to associate singular manifestations of leishmaniasis with individual species of Leishmania was opposed by the defenders of "Leishmanial unity," namely the notion that all the leishmaniases were caused by a single species, with behavior and clinical manifestations varying according to the local environment and the species of animal or insect that acted as the parasite's host.

None of the attempts to characterize the species based on attributes such as morphology, behavior in culture, infectiveness in laboratory animals, or immunological properties had solved this problem. Even the location in the body was relative, since skin parasitism had been observed in certain cases of visceral leishmaniasis. Visceralization of $L$. tropica and $L$. braziliensis could also occur, but only in laboratory animals, argued Samuel Pessôa (1961, p.41), a "pluralist." For this parasitologist, the Deanes, Garnham, Adler, and others, each form of leishmaniasis had its own specific agent.

In 1953, Francisco Biagi Filizola of the Universidad Nacional Autónoma de México proposed differentiating the four varieties of American tegumentary leishmaniasis into the mucocutaneous form found in tropical humid forests (espúndia), the dry cutaneous form (uta), a benign form called pian bois, and chiclero ulcer (Biagi, 1953). ${ }^{36}$

The mucocutaneous disease (espúndia), which had a significant presence in Brazil and other countries, especially those that shared the Amazon rainforest, erupted in epidemics when forests were cleared to build villages or farms, to construct railroads or highways, or when people moved through these environments during wars or revolutions. In this form of leishmaniasis, nasal complications occurred in approximately $80 \%$ of cases, and approximately $30 \%$ had lesions in the mucous membranes, leading to repulsive deformities and often death from septic broncho-pneumonia.

The Peruvian Pedro Weiss (1943) demonstrated that espundia was propagated in the same areas as malaria, while uta raged in high regions of the Andes devoid of forests. Uta manifested as skin lesions, without metastatic involvement of the mucous membranes. This rural disease could spread to urban areas, affected more children than adults, and dogs were frequently parasitized, as in Mediterranean or infantile visceral leishmaniasis.

Pian-bois (French) or bosch yaws (Dutch), a benign form of cutaneous leishmaniasis, was found in northern South America and Central America (the Guyanas, Panama, Costa Rica). Small ulcerated lesions healed spontaneously, and the mucosae were invaded in only 5\% of cases. Chiclero ulcers in Mexico (Yucatan) and Guatemala or bay sore in British Honduras only affected the ears and could cause progressive disfigurement of this organ. ${ }^{37}$ Diffuse tegumentary leishmaniasis, very similar to lepromatous leprosy, was described in 1948, separately, by two Venezuelan dermatologists, Jacinto Convit of the Medical School of the Central University of Venezuela and Pedro Lapenta (who would later direct a leprosarium on Providencia Island, from 1949 to 1953), and by Luiz Prado Barrientos, a professor of tropical diseases at San Andrés University in La Paz, Bolivia (Convit, Lapenta, 1948; Barrientos, 1948). ${ }^{38}$ Diffuse tegumentary leishmaniasis was characterized by the spread of lesions throughout the body and a marked decrease in immune response. Antimonial drugs that were relatively effective in the other leishmaniases had no influence in this form of the disease.

The epidemiology and clinical manifestations of American tegumentary leishmaniasis therefore differed so much from region to region that it was inevitable to suppose there 
must be several Leishmania involved. Biagi (1953) linked chiclero ulcer to the subspecies Leishmania tropica mexicana. Hervé Alexandre Floch (1954a; 1954b), of the Pasteur Institute of French Guyana and Inini, incriminated L. tropica guyanensis as the cause of pian bois and uta, and Leishmania tropica braziliensis as the agent of espúndia. In a study published in 1961, Samuel Pessôa proposed another classification that restored the sovereignty of Leishmania braziliensis (Table 1).

Table 1: Synopsis of leishmaniasis classification by Samuel Pessôa

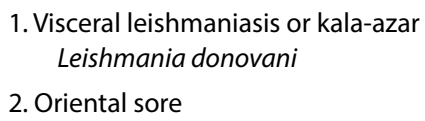

3. American tegumentary leishmaniasis

a) Mucocutaneos leishmaniasis, ferida brava or espúndia L. braziliensis braziliensis (Biagi had proposed Leishmania tropica braziliensis)

b) Tegumentary leishmaniasis from the Peruvian mountains or uta L. braziliensis peruviana (Pessôa used the name peruviana suggested by Vélez López) ${ }^{39}$

c) Tegumentary leishmaniasis of northern South America and Central America, pian-bois or bosch yaws L. braziliensis guyanensis (Pessôa altered the classification proposed by Floch: Leishmania tropica guyanensis)

d) Mexican tegumentary leishmaniasis or chicleros ulcer

L. braziliensis mexicana (altered the classification proposed by Biagi: Leishmania tropica mexicana)

e) Diffuse tegumentary leishmaniasis - L. braziliensis pifanoi (species proposed by Medina e Romero, 1959)

Source: extracted from Pessôa (1961, p.48-49).

Garnham and the specialists behind Tropical health: a report deemed comparative studies essential, thus defending Saul Adler's proposal at the sixth International Congress of Tropical Medicine and Malaria held in Lisbon in 1958 to create centers to maintain Leishmania strains isolated in different parts of the world. ${ }^{40}$ In 1965 this project became a reality, and can be seen as an important milestone in more decisive WHO involvement in the leishmaniases problem. An agreement between this agency and Hebrew University in Jerusalem created the first WHO International Reference Centre for Leishmaniasis, directed by Adler (WHO, 1965).

An important collaborator for Adler was Marcello de Vasconcellos Coelho. In 1961, when he took over as head of the Leishmaniasis Research Center Laboratory in Belo Horizonte, Adler was in Brazil and visited this institution. He was also one of the members of the working group set up by Amilcar Vianna Martins, director of DNERu, to analyze problems related to leishmaniasis and other rural endemics prevalent in Brazil (DNERu, 1962). Marcello Coelho completed a six-month internship at Hebrew University shortly afterward through a Special Research Training Grant from the World Health Organization. There, with Adler, he studied techniques for maintaining samples of Leishmania, and especially immunobiological techniques used to decipher the antigenic composition of various strains in order to identify them specifically.

Both Coelho and Adler presented their work in the seventh International Congress of Tropical Medicine and Malaria, held in Rio de Janeiro in September 1963. The professor 
at the Hadassah Medical School, who would die three years later (on January 26, 1966), presented his efforts to differentiate L. braziliensis from L. mexicana and L. tropica by comparing its behavior when raised on a semi-solid medium made from homologous and heterologous sera (Adler, 1963).

In British Honduras, Ralph Lainson of the London School of Hygiene and Tropical Medicine and John Strangways-Dixon, an entomologist from the University of the West Indies in Kingston, Jamaica, had been trying to experimentally transmit the Leishmania responsible for chicleros ulcer via Phlebotomus since 1959. Various wild-captured species were fed from lesions on hamsters, and then refed on human volunteers. During the second blood meal, four days after the first meal on the infected hamster, the phlebotomine fly ${ }^{41}$ transmitted the parasite to a volunteer: J.S.D., Lainson's colleague. The successful experiment was reported in a research note (Strangways-Dixon, Lainson, 1962). "It was the first experimental proof of transmission of a neotropical Leishmania to man through the bite of a phlebotomine," as described by Mun-Keat Looi (2011) and Shaw (2015, p.225). At this time, Garnham was annoyed by the restrictions imposed by WHO on the use of humans in experimental medicine, which hampered his malaria program. "I'm sure that was what he thought of," Lainson (1995, p.129-130) wrote, "when he learned of our first experimental transmission ... Garnham sent me and John Strangways-Dixon a short, but rebellious telegram: 'Congratulations on your beautiful human experiment.'”

Saul Adler and especially P.C.C. Garnham were key players in constructing a new international network addressing the leishmaniases, linking mostly isolated teams in the Old and New Worlds with the support of WHO, PAHO, and organizations such as the Wellcome Trust. I am studying this network from the viewpoint of the New World leishmaniases, which received more exposure after research conducted by British scientists in Central America and then Brazil. After the 1964 military coup, large-scale public works in the interior of Brazil transformed American tegumentary leishmaniasis into an extremely serious problem in the Amazon region (Peixoto, 2017; Guerra et al., 2015). In 1965 at the Evandro Chagas Institute in Belém, Pará, Ralph Lainson and Jeffrey Shaw, who were Garnham's disciples at the London School of Hygiene and Tropical Medicine, founded the Wellcome Parasitology Unit. Lainson, Shaw and their foreign and Brazilian collaborators showed that populations of parasites in the American continent, with their respective vectors and vertebrate hosts, were much more heterogeneous than had been imagined..$^{42}$ Philip Davis Marsden, who also came from the London School of Hygiene and Tropical Medicine, began to teach tropical medicine in 1967 at the University of Brasília and soon became a leading authority in controlling the leishmaniases. Jorge Arias and Toby Vincent Barrett established the Leishmaniasis and Chagas Disease Laboratory at the National Institute of Amazonian Research (INPA) in the 1980s.

Research on the leishmaniases was stimulated by the WHO Special Program for Research and Training in Tropical Diseases (TDR), which was conceived in the 1970s to bridge the science gap in the study and control of neglected diseases affecting impoverished populations in the Americas, Africa, and Asia. In the 1980s, experts mobilized by WHO produced inventories on national leishmaniasis control programs, which for the most part were very precarious, and began to publish recommendations on how the participating 
nation states should work to achieve control of this complex of diseases on multiple fronts. In May 2007, the 60th World Health Assembly adopted a resolution on controlling the leishmaniases, in which it urged member states to make more consistent efforts toward establishing epidemiological surveys, control programs, systems for monitoring and data collection and analysis, actively seek out cases and access to means of diagnosis and treatment. These states were expected to more effectively promote prevention, which included greater awareness of the leishmaniases at the community level as well as cooperating with neighboring countries that shared endemic areas. The resolution also called on WHO to take the lead in establishing effective control programs in the affected regions (WHO, 2007). In future work, I hope to analyze the varied interfaces between the $\mathrm{PAHO}$ and WHO control programs and the countries in the Americas that found themselves at odds with the resurgence of both human and canine visceral leishmaniasis as well as American tegumentary leishmaniasis.

\section{Final considerations}

Ralph Lainson died in Belém, in May 5, 2015. In August 11, Elizabeth Rangel, renowned expert in the insect vectors of Leishmania, that, still young, had established work relations with Lainson and Shaw e and with Leônidas and Maria Deane, then at Oswaldo Cruz Foundation, talked about leishmaniasis and these researchers during the third Commemorating Meeting of the National Week for the Control of the Leishmaniases in Oswaldo Cruz Institute/Fiocruz. I was in the audience to familiarize myself with a subject that was new for me. I heard excellent and very instructive lectures, but I left deeply impressed with the amount of problems and controversies that still surround this complex so complex of diseases. There could be no better stimulus for a historian interested in sciences and health.

At the end of the twentieth century in Brazil and in other countries, all forms of leishmaniasis emerged or reemerged in urban and rural areas due to environmental changes, human migrations, chaotic urban growth, wars and other socioeconomic processes underway in large expanses of these countries. ${ }^{43}$ Visceral leishmaniasis acquired severe forms when occurring concomitantly with other infections, such as AIDS.

The leishmaniases were then classified as neglected tropical diseases. Although they are in fact overlooked by public policies and affect neglected populations, they mobilize one of Brazil's most vigorous research communities. This is partly due to the fact that many uncertainties still remain about transmission mechanisms, diagnostic techniques, treatment, and prevention.

At the same time, investigations on the leishmaniases were reframed by new paradigms, especially molecular biology, with increasing numbers of students trained in this discipline in graduate courses that spread across Brazil and other countries in the Americas. Molecular biology has had a major impact on knowledge production about all forms of the disease, including the development of diagnostic techniques, therapeutics and vaccines.

The growing specialization among the professionals who address the leishmaniases and other neglected diseases today would appear to be counterbalanced (with exceptions, 
of course) by an inability to perceive the problem holistically, unlike the multivalent generation of P.C.C. Garnham, Samuel Pessôa, and Leônidas Deane, who were sensitive to the social and environmental determinants of the leishmaniases and other endemic diseases. On the other hand, the ethical standards for scientific research have changed considerably, and as a result some practices that used to be routine in human and animal research before the post-war period have become unthinkable among new generations of physicians and researchers. This is because the leishmaniases, like any other disease, are also a cultural event which depends on the categories of thought and verbal constructs that are specific to a generation, reflecting the history of the medical field and the surrounding society.

\section{AKNOWLEDGEMENT}

This research had funding from Fundação Carlos Chagas Filho de Amparo à Pesquisa do Estado do Rio de Janeiro (Faperj) through Programa Cientista do Nosso Estado, call n.26/2014.

\section{NOTES}

${ }^{1}$ On this topic, see Dutta (2009, p.93-112; 2016, p.72-76); Jogas Jr. (2017, p.1051-1070); Benchimol, Jogas Jr. (2020).

${ }^{2}$ Work by Antonio Carini and Ulysses Paranhos (the director and a research assistant at the Pasteur Institute of São Paulo, respectively) and Adolpho Carlos Lindemberg (who headed the dermatology department at Santa Casa de Misericórdia and conducted research at the Instituto Bacteriológico de São Paulo) is analyzed in detail in Jogas Jr. (2017, p.1051-1070) and Benchimol e Jogas Jr. (2020). The case of visceral leishmaniasis observed in Paraguay, and two others subsequently diagnosed in Argentina, were seen as isolated events in stark contrast with hundreds of cases of tegumentary leishmaniasis described by Latin American doctors, suggesting that the dermatological disease could also attack the viscera.

${ }^{3}$ On Evandro Chagas' work on visceral leishmaniasis, see Gualandi (2013), Deane (1986, p.53-67) and Benchimol et al. (2019, p.611-626).

${ }^{4}$ The Commission included three researchers from the Oswaldo Cruz Institute, Aristides Marques da Cunha, Gustavo de Oliveira Castro, Leoberto de Castro Ferreira, and the Argentine Cecílio Romaña. Evandro Chagas had financial support from the Oswaldo Cruz Institute, the Rockefeller Foundation, and a Brazilian businessman, Guilherme Guinle. Evandro Chagas's relationship with these sponsors of his activities is analyzed in Barreto (2012).

${ }^{5}$ In Belém do Pará, other characters were soon incorporated into his team: the English nurse Agnes Stewart Waddel, who would become his second wife, Leônidas and Gladstone Deane, from Pará, Felipe NeryGuimarães, and Maria von Paumgartten, who would later marry Leônidas Deane.

${ }^{6}$ The original name (Leishmania brasilienses) was altered to L. braziliensis by Vianna himself in a 1914 article, but the name Leishmania brasiliensis (with the s) is still found in many scientific articles up through the 1960s.

7 "Tratamento da leishmaniose pelo tártaro emético" [Treatment by emetic tartar] was a communication presented in a session of the Brazilian Society of Dermatology during the seventh Brazilian Congress on Medicine and Surgery, in Belo Horizonte, the capital of Minas Gerais, in April 1912 (Vianna, 1912). In India, after 1922 emetic tartar was replaced by urea stibamine, a pentavalent antimony developed by Upendranath Brahmachari. Other antimonial compounds such as Fuadin, were produced by pharmaceutical companies like Bayer. On this topic, see Brahmachari (1940), Marsden (1985) and the fourth chapter of Jogas Jr. doctoral thesis (2019, p.145-175): "Caminhos para o tratamento: os compostos antimoniais e a terapêutica da leishmaniose tegumentar americana" [Approaches to treatment: antimonial compounds and therapeutics of American tegumentary leishmaniasis].

${ }^{8}$ On this, see Gualandi (2013); Barreto (2012) and Deane (1986).

${ }^{9}$ A total of 14 cases were diagnosed by viscerotomy in Pará between 1932 and 1940; Evandro Chagas and his team identified eight living cases. 
${ }^{10}$ The blood of an infected dog was consumed by females of P.longipalpis, and Leishmania identical to those in the protozoan cultures were found in two of these insects (Ferreira, 1938). Phlebotomus intermedius was also infected using animals with leishmaniasis. And it was with this fly that Agnes Chagas and Wladimir Lobato Paraense obtained their first positive results for transmission of visceral leishmaniasis to a hamster via Phlebotomus (Paraense, Chagas, 1940; Chagas, 1939).

${ }^{11}$ Adler assumed the directorship of the Department of Parasitology, which was later incorporated into the Hadassah Medical School, opened soon after the creation of the State of Israel in 1948. Here my main sources are Shortt (1967) and Telkes (1988).

${ }^{12}$ Authors like Dedet (2007) and Théodoridès (1997) see this as the initial evidence that phlebotomines were the vectors of leishmaniasis. Killick-Kendrick (2013) emphasizes the work done by Swaminath, Shortt, Anderson (1942).

${ }^{13}$ Aragão published a note on this in 1922 (p.129-130) and a more comprehensive work in Memórias do Instituto Oswaldo Cruz in 1927 (p.177-186). As we have seen, another species described by Lutz and Neiva (1912), Phlebotomus longipalpis (today known as Lutzomyia longipalpis), was later associated with transmission of visceral leishmaniasis by Evandro Chagas and his team in 1936-1937.

${ }^{14}$ The experiments consisted of crushing naturally infected flies and introducing this material into skin lesions created on human volunteers. Adler, Theodor (1925a, 1925b, 1926).

${ }_{15}$ Adler cited Cunha, Chagas, "Estudos sobre o parasito" [Studies on the parasite], part 3 (p.329-337) of the report by Chagas et al. (1937) on work done during 1936.

${ }^{16}$ In this and other citations of texts from non-English languages, a free translation has been provided.

${ }^{17}$ On the professional trajectory and political thinking of Samuel Pessôa, see Hochman (2015) and Paiva (2015). The parasitological works on leishmaniasis from University of São Paulo are analyzed in Benchimol, Jogas Jr. (2020).

${ }^{18}$ On this subject, see Hochman (2009).

19 This and other articles by Soviet researchers were reviewed and/or commented on by the British parasitologist Cecil Arthur Hoare (1954).

${ }^{20}$ Of the 188 patients who lived in the area chosen for the Deanes' study, 177 had been infected in rural areas (96\%) and seven (4\%) in the city of Sobral. This number would rise to 14 in September 1955.

${ }^{21}$ On the gambiae campaign see Anaya (2020).

${ }^{22}$ Research was important to calibrate the use of DDT against Phlebotomus longipalpis: Deane, Deane, Alencar (1955). At least until 1960, the use of this residual insecticide in Ceará continued to be experimental in nature, since it was applied in one group of 14 municipalities, but not in another so as to evaluate the relative efficacity of other prophylactic measures (Alencar, 1961).

${ }^{23}$ Translated to English, the title of the article published in the first page of Correio da Manhã, an important newspaper of Rio de Janeiro, still the Brazilian capital that would move to Brasília two years later, read: "Minister Mário Pinotti promises a sick Brazil better days: New generations will no longer suffer from five terrible afflictions - Preventing the deaths of 500,000 children per year - Basic sanitation and hospital care - The fight against tuberculosis, leprosy, cancer, mental illness, and sanitary improvements - the program of the new cabinet member for Health" (Ministro..., 8 jul. 1958).

${ }^{24}$ There are two versions, a complete 540-page version (Tropical health: a report on a Study of Needs and Resources), and a summary (Tropical health: summary report on a Study of Needs and Resources) with 121 pages. They will be referred to here as the NAS (1962a, 1962b).

${ }^{25}$ The list of consultants also included P.C. Sen Gupta, of the Calcutta School of Tropical Medicine in India, but the book does not contain his opinion. A summary of the opinions produced by the rapporteur Willard H. Wright can be found in NAS (1962b, p.59-60) and in NAS (1962a, p.376-377). The opinion of Leônidas M. Deane is found in 1962a (p.505), of Marshall Hertig in 1962a (p.505-508), and Philip Edmund Clinton Manson-Bahr (1962a, p.508).

${ }^{26}$ The classifications minor and major were proposed in 1915 by a mission organized to study the tropical diseases of men and animals in Turkmenistan, which at that time was a province of tsarist Russia. The expedition found that the lesions called by different local names and seen by doctors in the region as different diseases represented a single illness (Yakimoff, Schockov, 1915). In the 1940s, three Soviet researchers (Latyshev, Kryukova, and Mirzoian) justified the existence of two "races" of Leishmania tropica from clinical and epidemiological differences in illnesses they produced and immunobiological 
differences. Kryukova showed that the two parasites could be differentiated by inoculation into gerbils and white mice: these animals were resistant to L. tropica minor (the dry type), but the agent of the wet type (L. tropica major) produced infections. References to this research can be found in the invaluable work by Heyneman, Hoostraal, Djigounian (1980).

${ }^{27}$ In a letter to Falcão, Deane (7 nov. 1959) enclosed a copy of what he had written to Fay at WHO on November 4, 1959 about the tests involving Phlebotomus longipalpis and Dieldrin. The Leônidas Deane Collection only holds the results from his experiments with DDT.

${ }^{28}$ The International Cooperation Administration (ICA) was the US agency responsible for external assistance and non-military security programs from June 30, 1955 to September 4, 1961. It was the predecessor of the US Agency for International Development (USAID).

${ }^{29}$ Garnham considered mechanical transmission by ticks and stable flies possible, as well as contagion via the respiratory or digestive tract and (more rarely) congenital or venereal infection.

${ }^{30}$ Adler and Theodor (1957) conducted a literature review on the role of the dog as an important reservoir host of Leishmania donovani in areas of visceral leishmaniasis in the Mediterranean, China, Caucasus, and South America, as well as the jackal.

${ }^{31}$ In Turkmenistan, a country in Central Asia, outbreaks of human infections of L. tropica were found to be associated with infected wild gerbils and ground squirrels. Phlebotomus caucasicus and P. papatasii living in burrows of the rodents maintained the infection among them. P. papatasii seemed to be the vector of the parasite from the rodent to man (Latyschev, Kryukova, 1941; Shekhanov, Suvorova, 1960).

32 Inconclusive results were obtained by Pedroso (1913, 1923) and Leônidas and Maria Deane (1955a) in Brazil, by Mazza (1926, 1927) and Romaña et al. (1949) in Argentina; and by Felix Pifano (1940) in Venezuela. Negative results were more frequent in the literature; for example, Migone (1913) in Paraguay, Gordon and Young (1922) in Amazonas, and Pessôa and Barreto (1948) and Forattini, Pattoli, Aun (1953) in São Paulo. A good analysis of this literature can be found in Forattini (1960b) and Pessôa (1961). The role of dogs in visceral leishmaniasis was analyzed in two substantial theses: Joaquim Eduardo Alencar (1959), Calazar canino: contribuição para o estudo da epidemiologia do calazar no Brasil [Canine kalazar: a contribution to the study of its epidemiology in Brazil] and Zigman Brener (1957), Calazar canino em Minas Gerais [Canine kalazar in Minas Gerais].

${ }^{33}$ In 1951, the Peruvian physician published four articles on $u t a$ : they addressed dogs from endemic areas, experimental infection of foxes, the epidemiology of $u t a$, and the role of phlebotomine sandflies in the transmission of this cutaneous leishmaniasis (Herrer, 1951a; 1951b; 1951c; 1951d).

${ }^{34}$ At that same time, they published studies on tegumentary leishmaniasis in the territory of Amapá (Forattini et al., 1959; Forattini, 1960c) and in the southern region of the state of Mato Grosso (Forattini, 1960a).

35 The findings about wild hosts in Panama are analyzed in Lainson, Shaw (1973).

${ }^{36}$ Head of the Department of Microbiology and Parasitology at the UNAM medical school, Biagi was the first Mexican doctor to work in the World Health Organization (WHO). He was the author of Enfermedades parasitarias [Parasitary diseases], a classic work of Mexican parasitology (Bermúdez, 2013).

${ }^{37}$ The epidemiology of this form of leishmaniasis was studied by Biagi and by Garnham, Lewis (1959).

${ }^{38}$ Convit (1958) considered it a new disease and described its characteristics. He adapted a vacine against leprosy for leishmaniasis. The Venezuelans Medina, Romero (1959) also published on diffuse leishmaniasis.

${ }^{39}$ Vélez López (1913) is in fact a letter published in Bulletin de la Societé de Pathologie Éxotique and written in July 23, 1913, in Trujillo. Felix Mesnil discusses his findings and the name proposed for the Peruvian Leishmania. "If it really differs from L. tropica and L. americana, this is a problem still difficult to solve that requires new researches. A priori, it seems probable that the names uta and espúndia refer to the same and unique disease" - wrote the French parasitologist.

${ }^{40}$ Various strains maintained in cultures, hamsters, and in deep freeze could be compared in terms of morphology (since they already had electron microscopy), immunological behavior, and development in different species of phlebotomines and vertebrates. Essential for these studies were specific serology such as group reactions, and immunology involving cross-immunity and the Montenegro reaction, testing the validity of this diagnostic technique in other leishmaniases beyond the American cutaneous variety. The agar precipitation test could be useful, and Deane mentioned his colleague Victor Nussensweig at the USP department of parasitology and his expertise in the technique (NAS, 1962a, p.506). 
${ }^{41}$ In an article published in 1963, the insect was classified as Phlebotomus paraensis Costa Lima, but was later reclassified as Lutzomyia pessoana. Subsequent studies carried out in Belize and the Yucatan Peninsula indicated that the vector for L. mexicana was Lutzomyia olmeca.

${ }^{42}$ Among many works, see Lainson (2010, p.13-32).

${ }^{43}$ In Pará, for instance, the situation of visceral leishmaniasis has not changed in the decades following the studies done by Evandro Chagas and his team, "however, in the early 1980s the disease resurfaced with a greater frequency in rural foci and in the suburban and urban areas of medium-size cities as Santarém ... In the last two decades, the expansive process increased due to the deforestation, socio-economic factor and unorganized occupation in the outskirts of cities, where the presence of Lutzomyia longipalpis in the peri-domicile human area and the domestic dog highly susceptible to infection have facilitated its dissemination. Actually, AVL [American visceral leishmaniasis] has already arrived in the Metropolitan Region of Belém (Cotijuba island), capital of Pará" (Silveira et al., 2016, p.15).

\section{REFERENCES}

ADLER, Saul.

Differentiation of Leishmania brasiliensis from L. mexicana and L. tropica. In: International Congress on Tropical Medicine and Malaria, 7., 1963, Rio de Janeiro. Proceedings... Rio de Janeiro: OMS (v.2, division A: tropical medicine: helminthic and protozoal infections). p.308309. 1963.

\section{ADLER, Saul.}

Attempts to transmit visceral leishmaniasis to man: remarks on the histopathology of leishmaniasis. Transactions of the Royal Society of Topical Medicine and Hygiene, v.33, n.4, p.419437. 1940a.

ADLER, Saul.

Notas sobre Leishmania chagasi. Memórias do Instituto Oswaldo Cruz. v.35, n.1, p.173$175.1940 \mathrm{~b}$.

ADLER, Saul; THEODOR, Oskar. Transmission of disease agents by phlebotomines and flies. Annual Review of Entomology, v.2, p.203-226. 1957.

ADLER, Saul; THEODOR, Oskar. Further observations on the transmission of cutaneous leishmaniasis to man from Phlebotomus papatasii. Annals of Tropical Medicine and Parasitology, v.20, n.2, p.175-194. 1926.

ADLER, Saul; THEODOR, Oskar. Letter to editor: The experimental transmission of cutaneous leishmaniasis to man from Phletotomuspapatasii. Nature, v.116, p.314-315. 1925a.

ADLER, Saul; THEODOR, Oskar.

The experimental transmission of cutaneous leishmaniasis to man from Phletotomus papatasii. Annals of Tropical Medicine and Parasitology, v.19, n.3, p.365-371. 1925b.
ALENCAR, Joaquim Eduardo de. Investigações em torno de foco de calazar na Paraíba. Revista de Malariologia e Doenças Tropicais, v.14, n.4, p.367-369. 1962.

ALENCAR, Joaquim Eduardo de. Profilaxia do calazar no Ceará. Revista do Instituto de Medicina Tropical de São Paulo, v.3, n.4, p.177-178. 1961.

ALENCAR, Joaquim Eduardo de. Calazar canino: contribuição para o estudo da epidemiologia do calazar no Brasil. Tese (Livre-docência da Cadeira de Parasitologia) - Faculdade de Medicina da Universidade do Ceará, Fortaleza. 1959.

ALENCAR, Joaquim Eduardo; HOLANDA, Daltro; CAVALCANTE, J.D.N.

Calazar no Vale do Jaguaribe: Ceará, 1955. Revista Brasileira de Malariologia e Doenças Tropicais, v.8, n.1, p.33-47. 1956.

ALIANÇA...

Aliança para o Progresso. Centro de Pesquisa e Documentação de História Contemporânea do Brasil/Fundação Getulio Vargas (CPDOC/FGV). Verbete sem autor. Disponível em: <http:// www.fgv.br/cpdoc/acervo/dicionarios/verbetetematico/alianca-para-o-progresso-1>. Acesso em: 24 out. 2019. s.d.

ANAYA, Gabriel Lopes.

O feroz mosquito africano no Brasil: o alastramento silencioso e a erradicação do Anopheles gambiae (1930-1940). Rio de Janeiro: Editora Fiocruz. 2020.

ARAGÃO, Henrique de B.R.

Leishmaniose tegumentar e sua transmissão pelos Phlebotomus. Memórias do Instituto Oswaldo Cruz, v.20, n.2, p.177-186. 1927.

ARAGÃO, Henrique de B.R.

Transmissão de leishmaniose no Brasil pelo Phlebotomus intermedius. O Brasil Médico, v.36, n.1, p.129-130. 1922. 
BARRETO, Danielle C.S.

Uma trajetória familiar na ciência: Evandro Chagas (1905-1940) e o estudo das endemias rurais no Brasil. Dissertação (Mestrado em História das Ciências e da Saúde) - Casa de Oswaldo Cruz/Fiocruz, Rio de Janeiro. 2012.

BARRIENTOS, Luiz Prado.

Um caso atípico de leishmaniose cutâneomucosa (espúndia). Memórias do Instituto Oswaldo Cruz, t.46, n.2, p.415-418. 1948.

BENCHIMOL, Jaime Larry; JOGAS JR., Denis Guedes.

Uma história das leishmanioses no Novo Mundo (fins do século XIX aos anos 1960). Belo Horizonte: Fino Traço; Rio de Janeiro: Editora Fiocruz. 2020.

BENCHIMOL, Jaime Larry et al.

Leishmanioses: sua configuração histórica no Brasil com ênfase na doença visceral nos anos 1930 a 1960. Boletim do Museu Paraense Emílio Goeldi. Ciências Humanas, v.14, n.2, p.611-626. 2019.

BERMÚDEZ, Kike.

Dr. Francisco Biagi-Filizola. Parcialmente disponível em: <https://pt.scribd.com/ document/124842282/Dr-Francisco-Biagi>. Acesso em: 10 dez. 2017. 2013.

BIAGI, Francisco.

Algunos comentários sobre las leishmaniasis y sus agentes etiológicos: Leishmania tropica mexicana, nueva subespécie. Medicina, v.33, n.683, p.401-406. 1953.

BRAHMACHARI, Upendranath.

Gleanings from my research. v.1: Kala-azar, its chemotherapy. Calcutta: University of Calcutta. 1940.

\section{BRENER, Zigman.}

Calazar canino em Minas Gerais. Tese (Doutorado em Medicina) - Universidade de Minas Gerais, Belo Horizonte. 1957.

BROWN, Theodore; CUETO, Marcos; FEE, Elizabeth.

A transição da saúde pública 'internacional' para 'global' e a Organização Mundial da Saúde. História, Ciências, Saúde - Manguinhos, v.13, n.3, p.623-647. 2006.

BRUMPT, Émile.

Précis de parasitologie. Paris: Masson. 1922.

CAMPOS, André L.V. de.

Políticas internacionais de saúde na Era Vargas: o Serviço Especial de Saúde Pública (1942-1960). Rio de Janeiro: Editora Fiocruz. 2006.

CHAGAS, Agnes Wadell.

Infecção de Phlebotomus intermedius pela Leishmania chagasi. O Brasil Médico, v.53, n.1, p.1-2. 1939.
CHAGAS, Evandro.

Primeira verificação em indivíduo vivo da leishmaniose visceral no Brasil (Nota prévia). $O$ Brasil Médico, v.11, n.50, p.221-222. 1936.

CHAGAS, Evandro et al.

Leishmaniose visceral americana (Nova entidade mórbida do homem na América do Sul): relatório dos trabalhos realizados pela Comissão Encarregada do Estudo da Leishmaniose Visceral Americana em 1936. Memórias do Instituto Oswaldo Cruz, v.32, p. 321385. 1937.

CHUNG, Huei-lan.

On the relationship between canine and human kala-azar in Peiping and the identity of Leishmania donovani and Leishmania canis. Chinese Medical Journal, v.37, n.6, p.501-523. 1940.

\section{CONVIT, Jacinto.}

Leishmaniasis tegumentaria difusa: nueva entidad clínico-patológica y parasitaria. Revista de Sanidad y Asistencia Social, v.23, n.1-2, p.1-28, fig.1-49. 1958.

CONVIT, Jacinto; LAPENTA, Pedro.

Sobre um caso de leishmaniose tegumentária de forma disseminada. Revista de La Policlinica, v.17, n.100, p.153-158. 1948.

CUETO, Marcos.

Saúde global: uma breve história. Rio de Janeiro: Editora Fiocruz. 2015.

DANTAS-TORRES, Felipe.

[Depoimento]. Entrevistador: Jaime L.

Benchimol. Recife: Centro de Pesquisas Aggeu Magalhães, Fundação Oswaldo Cruz. Gravação digital (1h45min) (Departamento de Arquivo e Documentação; Casa de Oswaldo Cruz/Fiocruz, Rio de Janeiro). 29 nov. 2016.

DEANE, Leônidas de Mello.

História do Instituto Evandro Chagas: período 1936-1949. In: Instituto Evandro Chagas.

Instituto Evandro Chagas: 50 anos de contribuição às ciências biológicas e à medicina tropical, v.1. Belém: Fundação Serviços de Saúde Pública. p.53-67. 1986.

DEANE, Leônidas de Mello.

Carta ao Dr. Richard Fay. Fundo Leônidas Deane, Série trajetória profissional - Docência USP, Parasitologia Médica, 1953-1964/Correspondências, 14.5 - LD/TP/19530617 (Departamento de Arquivo e Documentação, Casa de Oswaldo Cruz/Fiocruz, Rio de Janeiro). 19 abr. 1960.

DEANE, Leônidas de Mello.

Carta ao sr. Alberto Falcão. Fundo Leônidas Deane, Série trajetória profissional - Docência USP, Parasitologia Médica, 1953-1964/ 
Correspondências, 14.5 - LD/TP/19530617 (Departamento de Arquivo e Documentação, Casa de Oswaldo Cruz/Fiocruz, Rio de Janeiro). 7 nov. 1959.

DEANE, Leônidas de Mello. Epidemiologia e profilaxia do calazar americano. Revista Brasileira de Malariologia e Doenças Tropicais, v.10, n.4, p.431-444. 1958.

DEANE, Maria von Paumgarten; DEANE, Leônidas de Mello.

Leishmaniose visceral urbana (no cão e no homem) em Sobral, Ceará. O Hospital, v.47, n.1, p.75-87. $1955 \mathrm{a}$.

DEANE, Maria von Paumgarten; DEANE, Leônidas de Mello.

Observações sobre a transmissão da leishmaniose visceral no Ceará. O Hospital, v.48, n.3, p.95-114. 1955b.

DEANE, Leônidas de Mello; DEANE, Maria von Paumgarten.

Encontro de leishmanias nas vísceras e na pele de uma raposa, em zona endêmica de calazar, nos arredores de Sobral, Ceará. O Hospital, v.65, n.4, p.419-421. 1954.

DEANE, Leônidas de Mello; DEANE, Maria von Paumgarten; ALENCAR, Joaquim E.

Observações sobre o combate ao Phlebotomus longipalpis pela dedetização domiciliária, em área endêmica de calazar no Ceará. Revista Brasileira de Malariologia e Doenças Tropicais, v.7, n.1, p.131-141. 1955.

DEDET, Jean-Pierre.

Les découvertes d'Edmond Sergent sur la transmission vectorielle des agents de certaines maladies infectieuses humaines et animales. Bulletin de la Societé de Pathologie Exotique, v.100, n.2, p.147-150. 2007.

\section{DNERu.}

Departamento Nacional de Endemias Rurais. Combate às endemias rurais no Brasil. (Relatórios dos Grupos de Trabalho reunidos em 1960 na cidade do Rio de Janeiro). Rio de Janeiro: Ministério da Saúde. 1962.

DESOWITZ, Robert S.

The malaria capers: tales of parasites and people. New York: W.W. Norton. 1991.

DUTTA, Achintya Kumar.

Pursuit of medical knowledge: Charles Donavan (1863-1951) on kala-azar in India. Journal of Medical Biography, v.16, p.72-76. 2016.

DUTTA, Achintya Kumar.

Kala-azar in British India. In: PATI, Biswamoy; HARRISON, Mark (Ed.). The social history of health and medicine in Colonial India. New York: Routledge. p.93-112. 2009.
EDLER, Flavio; PIRES-ALVES, Fernando.

A educação médica: do aprendiz ao especialista. In: Teixeira, Luiz Antônio; Pimenta, Tania; Hochman, Gilberto. História da saúde no Brasil. São Paulo: Hucitec. p.101-144. 2018.

FALCÃO, Alberto Rocha.

Susceptibilidade ao DDT e ao Dieldrin, de uma população normal de Phlebotomus longipalpis, de Minas Gerais, Brasil. Revista Brasileira de Malariologia e Medicina Tropical, v.15, n.3, p.411415. 1963.

FERREIRA, Leoberto de Castro et al.

Notes on the transmission of visceral

leishmaniasis. O Hospital, v.14, n.5, p.2-3. 1938.

FLOCH, Hervé.

Leishmania tropica guyanensis n. s.p.: agent de la leishmaniose tégumentaire des Guyanes e de l'Amérique Centrale. Archives de l'Institut Pasteur de la Guyane Française, v.15, n.328, p.1-4. 1954a.

FLOCH, Hervé.

Leishmania tropica guyanensis n. sp. : agent de la leishmaniose tégumentaire des Guyanes e de l'Amérique Centrale. Bulletin de la Societé de Pathologie Exotique, v.47, n.6, p.784-787. 1954b.

FORATTINI, Oswaldo Paulo.

Sobre a leishmaniose tegumentar na região sul do estado de Mato Grosso, Brasil. Revista Brasileira de Malariologia e Doenças Tropicais, v.12, p.69-73. 1960a.

FORATTINI, Oswaldo P.

Sobre os reservatórios naturais da leishmaniose tegumentar americana. Revista do Instituto de Medicina Tropical de São Paulo, v.2, n.4, p.195203. $1960 \mathrm{~b}$

FORATTINI, Oswaldo Paulo.

Notas sobre Phlebotomus do Território do Amapá, Brasil (Dyptera, Psychodidae). Studia Entomologica, v.3, n.1-4, p.467-480. 1960c.

FORATTINI, Oswaldo Paulo; PATTOLI, Dino B.G.; AUN, José R.

Algumas observações sobre o comportamento da Leishmania braziliensis em cães. Arquivos da Faculdade de Higiene e Saúde Pública da Universidade de S. Paulo, v.7, n.2, p.137-155. 1953.

FORATTINI, Oswaldo Paulo et al. Leishmaniose tegumentar, no território do Amapá, Brasil. Revista do Instituto de Medicina Tropical de São Paulo, v.1, n.1, p.11-17. 1959.

GARNHAM, Percy Cyril Claude.

Problemes que posent a l'echelle mondialle la leishmaniose, l'amibiase, la trypanosomiases et la toxoplasmose, par le Professeur P.C.C. Garnham, consultant de l'OMS. World Health Organization, MHO/PA/101.60 - D60.2161 
(WHO Records and Archives, Geneva). 21 jun. 1960.

GARNHAM, Percy Cyril Claude; LEWIS, David J. Parasites of British Honduras with special reference to Leishmaniasis. Transactions of the Royal Society of Tropical Medicine and Hygiene, v.53, n.1, p.12-35. 1959.

GORDON, Rupert Montgomery;YOUNG, Charles James.

Parasites in dogs and cats in Amazonas. Annals of Tropical Medicine and Parasitology, v.16, n.3, p.297-300. 1922.

GUALANDI, Frederico da Costa.

Medicina tropical no Brasil: Evandro Chagas e os estudos sobre a leishmaniose visceral americana na década de 1930. Dissertação (Mestrado em História das Ciências e da Saúde) - Casa de Oswaldo Cruz/Fiocruz, Rio de Janeiro. 2013.

GUERRA, Jorge Augusto de Oliveira et al. Tegumentary leishmaniasis in the State of Amazonas: what have we learned and what do we need? Revista da Sociedade Brasileira de Medicina Tropical, v.48, supl.1, p.12-19. 2015.

HERRER, Aristides.

Estudios sobre leishmaniasis tegumentaria en el Peru, VI: relación entre leishmaniasis tegumentaria y Phlebotomus. Revista de Medicina Experimental, v.8, n.1-4, p.119-137. 1951a.

HERRER, Aristides.

Estudios sobre leishmaniasis tegumentária em el Peru, V: leishmaniasis natural em perros procedentes de localidades utógenas. Revista de Medicina Experimental, v.8, n.1-4, p.87-117. $1951 b$.

HERRER, Aristides.

Estudios sobre leishmaniasis tegumentária em el Peru, IV: observaciones epidemiológicas sobre la uta. Revista de Medicina Experimental, v.8, n.14, p.45-86. 1951c.

HERRER, Aristides.

Estudios sobre leishmaniasis tegumentária en el Peru, II: infección experimental de zorros com cultivos de leishmanias aisladas de casos de uta. Revista de Medicina Experimental, v.8, p.29-33. 1951d.

HERRER, Aristides.

Estudios sobre leishmaniasis tegumentaria en el Peru. Revista de Medicina Experimental, v.8, p.9137. 1949-1951.

HERRER, Aristides.

Nota preliminar sobre leishmaniosis natural en perros. Revista de Medicina Experimental, v.7, p.62-69. 1948.
HEYNEMAN, Donald; HOOSTRAAL, Harry; DJIGOUNIAN, Alice.

Bibliography of leishmania and leishmanial diseases. Cairo: United States Naval Medical Research Unit Number Three (NAMRU-s). 2v. 1980.

HOARE, Cecil Arthur.

Summary of recent abstracts. Tropical Diseases Bulletin, v.51, n.1, p.37-40. 1954.

HOCHMAN, Gilberto.

Samuel Barnsley Pessôa e os determinantes sociais das endemias rurais. Ciência e Saúde Coletiva, v.20, n.2, p.425-431. 2015.

HOCHMAN, Gilberto.

"O Brasil não é só doença": o programa de saúde pública de Juscelino Kubitschek. História, Ciências, Saúde - Manguinhos, v.16, supl., p.313331. 2009.

JOGAS JR., Denis Guedes.

Leishmaniose tegumentar americana em perspectiva histórica e global (1876-1944). Tese (Doutorado em História das Ciências e da Saúde) - Casa de Oswaldo Cruz, Fiocruz, Rio de Janeiro. 2019.

JOGAS JR., Denis Guedes.

Trópicos, ciência e leishmanioses: uma análise sobre circulação de saberes e assimetrias.

História, Ciências, Saúde - Manguinhos, v.24, n.4, p.1051-1070. 2017.

KEMP, Amy; EDLER, Flavio.

A reforma médica no Brasil e nos Estados Unidos: uma comparação entre duas retóricas. História, Ciências, Saúde - Manguinhos, v.11, n.3, p.569-585. 2004.

KILLICK-KENDRICK, Robert.

The race to discover the insect vector of kalaazar: a great saga of tropical medicine 19031942. Bulletin de la Société de Pathologie Exotique, v.106, p.131-137. 2013.

KRAMER, Paulo.

Punta del Este, Conferência de. Centro de Pesquisa e Documentação de História Contemporânea do Brasil/Fundação Getulio Vargas (CPDOC/FGV). Verbete. Disponível em: <http://www.fgv.br/ cpdoc/acervo/dicionarios/verbete-tematico/puntadel-este-conferencia-de. Accessed 24.10.2019>. Acesso em: 10 jul. 2020. s.d.

LAINSON, Ralph.

Espécies neotropicais de Leishmania: uma breve revisão histórica sobre sua descoberta, ecologia e taxonomia. Revista Pan-amazônica de Saúde, v.1, n.2, p.13-32. 2010.

LAINSON, Ralph.

The middle years at the London School of Hygiene and Tropical Medicine. In: Baker, John 
R. et al. Transactions of The Royal Society of Tropical Medicine and Hygiene, v.89, n.2, p.129131. 1995.

LAINSON, Ralph; SHAW, Jeffrey Jon. Leishmanias and leishmaniasis of the New World, with particular reference to Brazil. Paho Bulletin, v.7, n.4, p.1-19. 1973.

\section{LATYSCHEV, N.I.; KRYUKOVA, A.P.}

On the epidemiology of cutaneous leishmaniasis: the cutaneous leishmaniasis as a zoonotic of wild rodents in Turkmenia. Trudy Voenno Medicinskaya Akademia [Anais da Academia Médica Militar], n.25, p.229-241. 1941.

LATYSHEV, N.I.; KRYUKOVA, A.P.;

POVALISHINA, T.P.

Essays on the regional parasitology of Middle Asia, I: leishmanioses in Tadjikistan: materials for the medical geography of Tadjik S.S.R. (Results of expedition in 1945-1947). Problems of Regional, General and Experimental Parasitology and Medical Zoology, v.7, p.35-62. Disponível em: $<$ http://citeseerx.ist.psu.edu/viewdoc/downloa $\mathrm{d}$ ?doi=10.1.1.941.8641\&rep=rep1\&type $=$ pdf $>$. Acesso em: 5 jul. 2017. 1951.

LIMA, Nísia Trindade.

O Brasil e a Organização Pan-americana da Saúde: uma história em três dimensões. In: Finkelman, Jacobo (Org.). Caminhos da saúde no Brasil. Rio de Janeiro: Editora Fiocruz. p.24-116. 2002.

\section{LOOI, Mun-Keat.}

Life from a Wellcome Trust perspective, 75th stories: beautiful creatures: Ralph Lainson and his parasites. Wellcome Trust blog. Disponível em: <https://wellcometrust.wordpress. com/2011/06/02/75th-stories-beautifulcreatures-ralph-lainson-and-his-parasites/ ralphlainson_wtvm050939/>. Acesso em: 16 nov. 2017. 2011.

LU, C.C. et al.

New China's achievements in the treatment and prevention of kala-azar. Chinese Medical Journal, v.73, n.2, p.91-99. 1955.

LUTZ, Adolpho.

Waldmosquitos und Waldmalaria. Centralblatt für Bakteriologie, Parasitenkunde und Infektionskrankheiten, v.33, n.4, p.282-292.

[Reeditado em: Benchimol, Jaime Larry; Sá, Magali Romero. Adolpho Lutz: obra completa, v.2, livro 1: febre amarela, malária e protozoologia. Rio de Janeiro: Editora Fiocruz. p.733-743. 2005]. 1903.

LUTZ, Adolpho; NEIVA, Arthur.

Contribuição para o conhecimento das espécies do gênero Phlebotomus existentes no Brasil. Memórias do Instituto Oswaldo Cruz, v.4, n.1, p.84-95. [Republicado em Benchimol, Jaime Larry; Sá, Magali Romero (org.). Adolpho Lutz: obra completa, v.2, livro 4: entomologia. Rio de Janeiro: Editora Fiocruz. p.379-390. 2006]. 1912.

MALARIA...

Malaria eradication and bromeliad control in Trinidad. Foto de Maxine Rude. Fonds Photos, WHO/5822 (WHO Records and Archives, Geneva). 1954.

MARSDEN, Philip Davis.

Pentavalent antimonials: old drugs for new diseases. Revista da Sociedade Brasileira de Medicina Tropical, v.18, p.187-198. 1985.

MAZZA, Salvador.

Leishmaniosis cutánea en el caballo y nueva observación de la misma en el perro. Boletin del Instituto de Clínica Quirúrgica, v.3, p.462-464. 1927.

MAZZA, Salvador.

Leishmaniosis tegumentária y visceral. Boletin del Instituto de Clínica Quirúrgica, v.2, p.209-216. 1926.

MEDINA, Rafael; ROMERO, Jesus.

Estudio clínico y parasitológico de una nueva cepa de Leishmania. Archivos Venezoelanos de Patología Tropical y Parasitología Medica, v.3, n.1, p.298-326. 1959.

MIERES, Luis Enrique Migone.

Un cas de kala-azar a Assunción (Paraguay). Bulletin de la Societé de Pathologie Exotique, v.6, n.2, p.118-120. 1913.

MIGONE, Luis Enrique Migone.

La bouba du Paraguay, leishmaniose américaine. Bulletin de la Société Pathologie Exotique, v.6, n.3, p.210-218. 1913.

MINISTRO...

Ministro Mário Pinotti promete ao Brasil doente dias melhores... Correio da Manhã, ano 58, n.20.024, Primeira Página. Disponível em: <http:// memoria.bn.br/DocReader/089842_06/93453>. Acesso em : 9 jun. 2017. 8 jul. 1958.

MYRDAL, Gunnar.

Les aspects économiques de la santé. Chronique de l'Organisation Mondiale de la Santé, v.6, n.7-8, p.224-242. 1952.

NAS.

National Academy of Sciences. National Research Council. Division of Medical Sciences. Tropical health: a report on a Study of Needs and Resources. Washington: National Academy of Sciences; National Research Council. 1962a.

NAS.

National Academy of Sciences. National

Research Council. Division of Medical Sciences. Tropical health: summary report on a Study of Needs 
and Resources.Washington: National Academy of Sciences; National Research Council. 1962b.

NOTAS MÉDICAS.

Jornada sobre o calazar em Salvador. Correio da Manhã, ano 60, n.20.756, Segundo Caderno, p.2. Disponível em: <http://memoria.bn.br/ DocReader/089842_07/12442>. Acesso em: 2 ago. 2017. 23 nov. 1960.

\section{NOTAS MÉDICAS.}

Fundada a Sociedade Brasileira de Medicina Tropical. Correio da Manhã, ano 60, n.20.754, Segundo Caderno, p.2. Disponível em: <http:// memoria.bn.br/DocReader/089842_07/12312>. Acesso em: 8 fev. 2017. 20 nov. 1960.

\section{NOTAS MÉDICAS.}

Jornada sobre o calazar em Salvador. Correio da Manhã, ano 60, n.20.745, Segundo Caderno, p.2. Disponível em: <http://memoria.bn.br/ DocReader/089842_07/11942>. Acesso em: 2 ago. 2017. 10 nov. 1960.

\section{NOTAS MÉDICAS.}

Jornada sobre o calazar em Salvador. Correio da Manhã, ano 60, n.20.738, Segundo Caderno, p.2. Disponível em: <http://memoria.bn.br/ DocReader/089842_07/11645>. Acesso em: 2 ago. 2017. 1 nov. 1960 .

OMS.

Organização Mundial de Saúde. Trabalhando para superar o impacto global de doenças tropicais negligenciadas: primeiro relatório da OMS sobre doenças tropicais negligenciadas. Genebra: World Health Organization. 2010.

PAIVA, Carlos Henrique Assunção.

Parasitologia engajada: ciência e ensino em Samuel Pessoa. In: Hochman, Gilberto; Lima, Nísia Trindade (Org.). Médicos intérpretes do Brasil. São Paulo: Hucitec. p.320-342. 2015.

PARAENSE, Wladimir Lobato; CHAGAS, Agnes Waddel.

Transmissão experimental da leishmaniose visceral americana pelo Phlebotomus intermedius: nota prévia. O Brasil Médico, v.54, n.12, p.179-180. 1940.

PEDROSO, Alexandrino M.

Infecção do cão pela Leishmania tropica. Revista de Medicina, v.4, n.24, p.42-44. 1923.

PEDROSO, Alexandrino M.

Leishmaniose local do cão. Anais Paulistas de Medicina e Cirurgia, v.1, n.2, p.33-39. 1913.

PEIXOTO, Cláudio de Oliveira.

Leishmaniose tegumentar americana: história, políticas e redes de pesquisa no Amazonas (1970-2015). Dissertação (Mestrado em Condições de Vida e Situações de Saúde na Amazônia) - Instituto Leônidas e Maria Deane, Fiocruz, Manaus. 2017.
PENNA, Henrique A.

Leishmaniose visceral no Brasil. O Brasil Médico, v.48, n.46, p.949-952. 1934.

PESSÔA, Samuel Barnsley.

Classificação das leishmanioses e das espécies do gênero Leishmania. Arquivos de Higiene e Saúde Pública, v.26, n.87, p.41-50. 1961.

PESSÔA, Samuel Barnsley; BARRETTO, Mauro Pereira.

Leishmaniose tegumentar americana. Rio de Janeiro: Ministério da Educação e Saúde/Serviço de Documentação; Imprensa Nacional. 1948.

PIFANO, Felix.

La leishmaniasis tegumentaria en el estado Yaracuy, Venezuela. Revista de la Policlínica, v.9, n.55, p.3639-3658. 1940.

ROMAÑA, Cecílio et al.

Leishmaniosis tegumentária em perros de Tucumán, II: foco domestico de leishmaniosis. Anales del Instituto de Medicina Regional, v.2, n.3, p.283-292. 1949.

\section{SERGENT, Edmond et al.}

Transmission expérimentale du bouton d'orient (clou de Biskra) à l'homme par Phlebotomus papatasi (Scopoli). Annales de l'Institut Pasteur de Paris, v.40, n.5, p.411-430.1926.

SERGENT, Edmond et al.

Transmission de clou de Biskra par le phlébotome (Phlebotomus papatasi Scop.). Comptes Rendus Hebdomanires des Séances de l'Academie des Sciences de Paris, v.173, n.21, p.1030-1032. 1921.

SHAW, Jeffrey Jon.

In memory of Ralph Lainson: a parasitologist of amazing abilities. Acta Tropica, v.150, n.2, p.224226. 2015.

SHEKHANOV, M.V.; SUVOROVA, L.G. Nature foci of cutaneous leishmaniasis in the southwest of Turkmenistan. (In Russian, abstract in English). Meditsiskaya Parazitologya I Parazitarnye Bolezni [Parasitologia Médica e Doenças Parasitárias], v.29, n.5, p.524-528. 1960.

SHORTT, Henry Edward.

Saul Adler 1895-1966: elected FRS 1957. Biographical Memoirs of Fellows of the Royal Society, v.13, p.1-34. 1967.

SILVEIRA, Fernando Tobias et al. Revendo a trajetória da leishmaniose visceral americana na Amazônia, Brasil: de Evandro Chagas aos dias atuais. Revista Pan-amazônica de Saúde, v.7, número especial, p.15-22. 2016.

SOPER, Fred L. et al.

Yellow fever without Aedes aegypti: study of a rural epidemic in the Valle do Chanaan, Espírito 
Santo, 1932. American Journal of Hygiene, v.18, p.555-587. 1933.

STRANGWAYS-DIXON, John; LAINSON, Ralph. Dermal leishmaniasis in British Honduras: transmission of $\mathrm{L}$. brasiliensis by Phlebotomus especies. British Medical Journal, v.1, n.5274, p.297-299. 1962.

SWAMINATH, C.S.; SHORTT, Henry Edward; ANDERSON, L.A.P.

Transmission of Indian kala-azar to man by the bites of Phlebotomusargentipes. Indian Journal of Medical Research, v.30, n.3, p.473-477. 1942.

TELKES, Eva.

Dictionnaire biographique de la première génération de professeurs de l'Université Hébraïque de Jérusalem. Bulletin du Centre de Recherche Français à Jérusalem, v.2, p.39-51. Disponível em: <https://journals.openedition. org/bcrfj/4512>. Acesso em: 23 maio 2018. 1988.

THÉODORIDÈS, Jean.

Note historique sur la découverte de la transmission de la leishmaniose cutanée par les phlébotomes. Bulletin de la Societé de Pathologie Exotique, v.90, p.177-178. 1997.

THIAGO, Paulo de Tarso S.

História da malária em Santa Catarina. Dissertação (Mestrado em Saúde Pública)

- Universidade Federal de Santa Catarina, Florianópolis. 2003.

VÉLEZ LÓPEZ, Lizardo R.

Uta et espúndia. Bulletin de La Societé de

Pathologie Éxotique, v.6, n.8, p.545. 1913.

VIANNA, Gaspar.

Parasitismo da célula muscular lisa pela Leishmania braziliensis. Memórias do Instituto Oswaldo Cruz, v.6, n.1, p.39-42. 1914.

VIANNA, Gaspar.

Tratamento da leishmaniose pelo tártaro emético. Fala reproduzida na Quarta sessão ordinária da Sociedade Brasileira de Dermatologia realizada em 24 e 25 de abril de 1912, em Belo Horizonte, sob a presidência do professor Fernando Terra. Anais do VII Congresso Brasileiro de Medicina e Cirurgia, Belo Horizonte, Minas Gerais. Arquivos Brasileiros de Medicina, v.2, n.3, p.422-436. 1912.

VIANNA, Gaspar.

Sobre uma nova espécie de Leishmania (Nota preliminar). O Brasil Médico, v.25, n.41, p.411. 1911.

WEISS, Pedro.

Epidemiologia e clínica de La leishmaniosis tegumentária en el Peru. Revista de Medicina Experimental, v.2, n.3, p.209-248. 1943.

WHO.

World Health Organization. Leishmaniasis: fact sheet. Disponível em: <http://www.who.int/ mediacentre/factsheets/fs375/en/>. Acesso em: 7 ago. 2017. 2017.

WHO.

World Health Organization. Resolutions and decisions. WHA60.13: Control of leishmaniasis. Sixtieth World Health Assembly. Ninth plenary meeting: committee A, second report. Disponível em: <https://www.who.int/neglected_diseases/ mediacentre/WHA_60.13_Eng.pdf $>$. Acesso em: 26 nov. 2018. 2007.

WHO.

World Health Organization. WHO Research Programme on Leishmaniasis. Service to research workers. WHO/LEISH/1.65 - D65-454 (WHO International Reference Centre for Leishmaniasis, Jerusalem). 1965.

WINSLOW, Charles Edward.

Lo que cuesta la enfermedad y lo que vale la salud. Washington: Organización Mundial de la Salud; Oficina Sanitaria Panamericana. 1955.

YAKIMOFF, W.L.; SCHOCKOV, N.F.

Leishmaniose cutanée (Bouton d'Orient) au Turkestan Russe. Reunion Biologique de Petrograd, séance de janvier 1915. Comptes Rendus Hebdomanaires des Séances et Mémoires de la Société de Biologie, v.67. p.107-109. 1915.

\section{$\rightarrow \rightarrow \rightarrow<<<$}

